\title{
"Kami" and African PANPSYCHISM: An ECOPHILOSOPHICAL Appraisal
}

\author{
Mark Omorovie Ikeke
}

\section{ABSTRACT}

The planet is in the midst of an environmental crisis. Human behavior toward the environment is based on belief systems. Belief systems that are earth- or nature-friendly will help to preserve the earth more than those that are not. The paper posits, using hermeneutic and analytic methods, that the traditional Shinto idea of "kami" and the African panpsychic idea, which sees the presence of the divine or spirits in all things, provide a basis for the protection of the environment.

KEYWORDS: Shinto; kami; African Panpsychism; environment; traditional wisdom

The idea that traditional wisdom can be helpful in resolving the environmental crisis is an attractive one. Citing Tucker and Grim, Jacob Olupona writes that traditional wisdom is "very important in creating human views of nature and the way that people relate to nature and natural phenomenon." Beliefs about the environment shape our attitude and practices in regard to the environment. At the very least, indigenous wisdom cannot be dismissed as irrelevant. The United Nations General Assembly's Declaration on the Rights of Indigenous Peoples states the need "to maintain, control, protect and develop their cultural heritage, traditional knowledge and traditional cultural expressions, as well as the manifestations of their

'Jacob Olupona, "Religion and Ecology in African Culture and Society," in The Oxford Handbook of Religion and Ecology, ed. Roger Gottlieb (Oxford: Oxford University Press, 2006), 261. 
sciences, technologies and cultures." 2 This declaration implies that there is something valuable in indigenous ideas. Revisiting traditional wisdom may help us combat the environmental crisis. Among such traditional wisdom are the concept of "kami" in Shinto thought and the panpsychic idea in African cosmology.

\section{THE CONCEPT OF “KAMI” IN SHINTO}

The word Shinto comes from two Chinese words: shen ("spirit" or "god") and tao ("way"). By implication, the word Shinto means, "the way or path of the gods or spirits."

There is no monolithic understanding of Shinto, however. As Robert J. Kisala puts it, "Shinto is a complex reality, reflecting in its concrete and historical expressions several interwoven strands." ${ }^{3}$ In general, however, Shinto involves the acknowledgement of the existence of nature spirits, respect for clan ancestors, and activities to celebrate the seasons of the year. ${ }^{4}$ Florin Bonciu sums up the major elements of Shinto: "Shinto reflects the respect for nature and its powers, the respect for ancestors as well as the sense of dependence of people upon nature seen in the flow of the seasons and the cycles of agricultural activity."

At the core of Shinto thought is the concept of "kami." The concept is influenced by Buddhist, Confucian, and Daoist thought, but the concern here is with its meaning in ancient Japanese worldview. ${ }^{6}$ Though the word kami may be roughly translated as "gods," this translation may give rise to the image of an incarnationdeity or an object of worship, with which the term god is often equated in the West.' While deities in the Kojiki and Nihon Shoki are called kami, many things in nature

${ }^{2}$ United Nations, "Declaration of the Rights of Indigenous Peoples," art. 31, accessed May 10, 2013, http://www.un.org/esa/socdev/unpfii/documents/DRIPS_en.pdf.

${ }^{3}$ Robert J. Kisala, "Japanese Religions," in Religions in the Modern World: Traditions and Transformations, ed. Linda Woodhead, Hiroko Kawanami and Christopher Partridge (London: Routledge, $2009), 157$.

${ }^{4}$ Ibid.

${ }^{5}$ Florin Bonciu, "The Japanese Concept of Sustainable Development at a Global Level," Romanian Economic and Business Review 2 (2007): 2, accessed on September 10, 2013, ftp://ftp.repec.org/opt/ ReDIF/RePEc/rau/journal/SU07/REBE-SU07-.

${ }^{6}$ For details of how the kami idea has been influenced by these other religious philosophies and various epochs in Japan, see Inoue Nobutaka, "Perspectives towards Understanding the Concept of Kami," Institute for Japanese Culture and Classics, Kokugakuin University, accessed on September 10, 2013, www2.kokugakuin.ac.jp/ijcc/wp/cpjr/kami/into.html.

${ }^{7}$ Wendy Gleason, "Searching for Shinto: The Interplay of Politics and Religion from Yamato to the Heian Era," accessed on September 10, 2013, http://www.pcc.edu/library/sites/default/files/searching- 
can also be described as such: the sun, the moon, mountains, rivers, wind, lakes, and rocks. ${ }^{8}$ Even "the spirit of a historical figure such as an outstanding emperor, feudal lord, or scholar" can be kami. ' Citing Wonagga, Markham and Lohr give a classic definition of kami. They state that kami refers to various deities in heaven and earth, the spirits of deities, human beings, birds, plants, animals, trees, and all other things that incite awe and respect. ${ }^{10}$ Another formulation is Nelson's, as cited in Gleason: kami is "numinous, a formless power, present in everything, and more intense in certain objects, animals, or individuals," and "it can be experienced more strongly in certain natural manifestations, such as great trees or rocks or mountains or storms, but it is not limited to those locations." 11

In short, anything-whether object, person, place, or creature-that inspires awe and wonder can be referred to as kami. ${ }^{12}$ "What the kami symbolizes," according to Masakazu Hara, "is vitality, productivity, or fertility in this world."13 The notion of purification is related to kami. As Christopher Ives writes, "From early in their history, Japanese have regarded particularly awe-inspiring parts of their natural surroundings as kami. They have demarcated distinctive trees, rocks, waterfalls and even entire mountains as kami. Further, Shinto rites of purification serve to maintain or, if need be, restore harmony with those energies." ${ }^{14}$ In order for one to experience the presence of kami one must have "an aesthetically pure and cheerful heart, mind (kokoro), an emotional, mental and volitional condition that is not easily attained." 15 This implication is that one may encounter kami and not recognize it. The understanding and experience of kami, therefore, cannot be separated from ethical behaviors.

for-shinto.pdf. See also Yukitaka Yamamoto, "Nature in Shinto Tradition," accessed on September 10, 2013, www. Csuchico.edu/-gwilliams/tsa/peace5.html.

${ }^{8}$ Masakazu Hara, "Shinto," Encyclopedia of Science and Religion (2003), Encyclopaedia.com, accessed on October 15, 2013, http://www.encyclopedia.com/doc/1G2-3404200466.html.

${ }^{9}$ Ibid.

${ }^{10}$ Ian S. Markham and Christy Lohr, ed., A World Religions Reader (Malden, MA: Wiley-Blackwell, 2009), 132.

${ }^{11}$ Gleason, "Searching for Shinto."

${ }^{12}$ Bonciu, "The Japanese Concept of Sustainable Development at a Global Level."

${ }^{13}$ Hara, "Shinto."

${ }^{14}$ Christopher Ives, "Japanese Love of Nature," in Encyclopaedia of Religion and Nature, ed. Bron Taylor (London: Continuum, 2005), 900.

${ }^{15} J a m e s$ W. Boyd and Tetsuya Nishimura, "Shinto Perspectives in Miyazaki's Anime Film 'Spirited Away," Journal of Religion and Film 8, no. 2 (2004), www.unomaha.edu/jrf/Vol8No2/boydShinto.htm. 


\section{THE CONCEPT OF AFRICAN PANPSYCHISM}

The word panpsychism comes from pan ("all") and psychism ("spirit"). Panpsychism implies that the spirit or god is present in all things. Perhaps, one can understand the concept better by relating it to pantheism. According to Orlando Espin, pantheism is "a philosophical teaching claiming that all that exists is ultimately, an expression or appearance of one single reality." ${ }^{\prime 6}$ Although the term was first used in 1709, the idea behind it "goes back to the ancient Greeks and to classical Eastern religions."17 There are two understandings of pantheism, according to Espin. One sees God as the only and ultimate reality and all other things that exist are only appearances; the other sees God as immanent in all that exists and God is not separated from reality or beings. ${ }^{18}$

The traditional wisdom of Africa is colored by the idea that spirits permeate all reality. Ferguson writes that in Africa the cosmos is populated by divine beings and that the foremost of these is the all-powerful creator from whom the vital force (mana) flows into all of nature. ${ }^{19}$ T. Uzodinma Nwala in his study of the Igbo people of Nigeria similarly notes that for them objects possess a soul or vital force. Vital force is found in groves, rivers, mountains, caves, shrines, and stones. ${ }^{20}$ This idea of the presence of spirit in all things is what made some European scholars think of African religions as animist.

John S. Mbiti, however, argues that it is wrong to reduce African religions to animism, for there are many other features that characterise African religions. ${ }^{21}$ At least two alternatives have been established by non-European scholars. Professor Maduabuchi Dukor names this belief in the presence of God or spirits in everything as theistic panpsychism. This means that the African "sees God in every being and

${ }^{16}$ Orlando O. Espin, "Pantheism," in An Introductory Dictionary of Theology and Religious Studies, ed. Orlando O. Espin and James B. Nickoloff (Collegeville, Minnesota: Liturgical Press, 2007), 1000.

${ }^{17}$ Ibid.

${ }^{18}$ Ibid.

${ }^{19}$ Duncan S. Ferguson, Exploring the Spirituality of the World Religions: The Quest for Personal, Spiritual and Social Transformation (London: Continuum, 2010), 29.

${ }^{20} \mathrm{~T}$. Uzodinma Nwala, Igbo Philosophy: The Philosophy of the Igbo Speaking Peoples of Nigeria (New York: Triatlantic Books Limited, 2010), 50. There are many other authors who have corroborated the idea that Africans believe that spirits are present in all things in the cosmos. See M.P. Adogbo, "The Spirit World of African Peoples," in Contemporary Essays in the Study of Religions, ed. Samuel U. Erivwo and Michael P. Adogbo, vol. 1 (Lagos: Fairs and Exhibitions Nigeria Limited, 2000), 118; Richard J. Gehman, African Traditional Religion in Biblical Perspective (Nairobi: East African Educational Publishers, 2005), 250; Godwin Azenabor, Modern Theories in African Philosophy (Lagos: Byolah Publishers, 2010), 69.

${ }^{21}$ John S. Mbiti, Introduction to African Religion (Nairobi: East African Educational Publishers, 1991), 18. 
object manifesting as gods, spirits and forces." 22 Though in the African panpsychic paradigm vital force is present in all things and there is a multiplicity of deities and gods, these deities (divinities) are subjected to and are seen as messengers of the supreme deity, the almighty God. The almighty God created all other things including humans, other animals, plants and whatever there is.

Celestine Mgbaegbu has described the African belief in one almighty God in the midst of many gods as "mono-polytheism." ${ }^{23}$ In African ontology, the idea that spirit is present in all things, not just human life, is expressed by many writers, as Ogbenika has shown in his study. According to Placid Tempels, the Bantu people see life or vital force (spirit) in all things, including plants, animals, and stones. It is the life force that is responsible for all things being in existence. Moreover, these beings in the universe are in hierarchical order, so that a being with a higher force can influence a being lower in the hierarchy:

All creatures are found in relationship according to the law of a hierarchy. . . Nothing moves in this universe of forces without influencing other forces by its movement. The world of forces is held like a spider's web of which no single thread can be caused to vibrate without shaking the whole network. ${ }^{24}$

The fact is, like other indigenous peoples in the world, African people believe in the presence of spirits, gods, or divine presence in the universe. The cosmos is not void or empty of life. There is a life-force that makes things come into being, grow, mature, and even die in the process of life.

Just as the Japanese people see the kami presence in nature, so too do Africans see the mana (vital force) in nature. Africans, particularly in pre-colonial societies, have seen and experienced the presence of spirits in all things and have paid reverence to things in various degrees, and they have undergone various purification rituals when they violated the perceived laws of nature. In the modern, scientific, technological, and capitalistic age that has precipitated the environmental crisis, such beliefs must be acknowledged instead of dismissed. It may be asked how these can help foster environmental sustainability.

\footnotetext{
${ }^{22}$ Maduabuchi Dukor, Scientific Paradigm in African Philosophy: Theistic Panpsychic Epistemology and Ontology (Saarbrucken, Germany: Lap Lamberts Academic Publishing, 2010), 62.

${ }^{23}$ Celestine C.A. Mbaegbu, Hermeneutics of God in Igbo Ontology (Awka: Fab Educational Books, 2012), 335.

${ }^{24}$ Placid Tempels, Bantu Philosophy (Paris: Presence Africaine, 1959), 39-41.
} 


\section{KAMI, PANPSYCHISM, AND THE ENVIRONMENT}

The idea of kami and Shinto in general cultivate love of nature and provide a strong basis for environmental preservation. ${ }^{25}$ So too can the African panpsychic idea. In the Shinto understanding of kami, there is no dichotomy between human culture and nature. ${ }^{26}$ Because they are expressions of kami, various aspects of nature deserve respect. This is to say that "the animistic element of Shinto that respects the vitality immanent in nature should certainly have the potential to make a positive contribution to human efforts to preserve the natural environment." ${ }^{27}$

That the kami idea has led to environmental preservation is a conviction of the Association of Shinto Shrines. According to it, during ancient times the Japanese people looked at nature with deep reverence and appreciation, and they used to follow the principle "to return the thing given to the human as a gift of nature to its original place." Until the Edo era (1603-1867), Japanese society had functioned well. After that time, "with the development of the modern industry, the level of the Japanese life was elevated in terms of material life ... but ... the Japanese spirituality inherited from the ancient ancestors has been gradually lost or hidden somewhere deep into unconsciousness." It might not be an exaggeration, the Association contends, to say that "not only environmental conservation but also all problems of modern society have been caused by the lack of [awe], reverence, and appreciation for nature that ancient people used to have." 28

The sentiments of Callicott are echoed here: the concern is how to draw viable ecological ideas from the past to face today's unprecedented environmental crisis. ${ }^{29}$ There can be no gainsaying the fact that Shinto which is a "form of animistic nature worship, in which the divine 'kami' (deities, spirits, or gods) are believed to reside in animals, trees, rice fields, and certain human beings" is ecologically based for not only sentient beings, but mountains and land are reverenced..$^{30}$

Though some people have criticised Shinto for "lack of overt ethical discussion," there is "in actual fact . . . a wealth of ethical reflection built around the concept

${ }^{25}$ Ives, "Japanese Love of Nature," 900.

${ }^{26}$ Ibid.

${ }^{27}$ Hara, "Shinto."

${ }^{28}$ Association of Shinto Shrines, "Nature, It is Divine, Message from Shinto," accessed on January 10, 2014, http://www.jinjahoncho.or.jp/en/publications/nature.

${ }^{29} \mathrm{~J}$. Baird Callicott, Earth's Insights: A Multicultural Survey of Ecological Ethics from the Mediterranean Basin to the Australian Outback (Berkeley: University of California Press, 1994), 106.

${ }^{30}$ T. Yamauchi, "Japan," in Encyclopaedia of Environmental Ethics and Philosophy, ed. J. Baird Callicott and Robert Frodeman (Detroit: Gale Cengage Learning, 2009), 6. 
of kannagara-no-michi." ${ }^{31}$ Jean Herbert, as cited by Markham and Lohr, opines that it is not true that Shinto lacks an overt ethical discussion. There are many do's and don'ts which place obligations on humans. ${ }^{32}$ Shinto calls for sincerity of heart (makoto), which demands humility, joy, and gratitude for one's being in touch with the workings of kami and living within the harmony of nature, and reverence for the human and the natural environment. ${ }^{33}$ In Shinto, human nature is good and when polluted can be purified through the ritual of purification (misogi). ${ }^{34}$ The most dramatic of these purifications is misogi harai, accomplished by standing under a waterfall. ${ }^{35}$ This experience is transforming, uplifting, and it brings one in touch with the creative life-force of the universe. ${ }^{36}$ Through continuous purifications, humans can create positive relations with the environment.

It must be noted that some writers claim that only awe-inspiring features of nature are regarded as sacred and offered rigorous preservation. ${ }^{37}$ The idea that Japanese love of nature is weak and selective is corroborated by many scholars such as Allan Grapard, Augustin Berque, Yuriko Saito, Stephen R. Kellert and Conrad Totman. ${ }^{38}$ This idea, however, has been countered by Boyd and Williams who, reflecting on the life of a Shinto priest, note that the unfolding cosmos that Shinto speaks of cannot be reduced to an idealized miniaturized nature. ${ }^{39}$

Just as the Japanese people, especially in ancient times, saw various natural phenomena as kami and responded to nature in appreciation, using the gifts of nature prudently, so also African people see nature as deserving reverence and preservation. In African traditional wisdom, humans and nature flow into each other and co-exist. There is a distinction between humans and nature in African thought, but this fact does not mean that they are separate. Humans and nature interpenetrate each other, and Africans see nature as the source of their sustenance. The African concept of ukama affirms that the human being exists because of the

${ }^{31}$ Markham and Lohr, 138. The term kannagara-no-michi means "the Way of kami" (see John Bowker, "Kami no michi," Concise Oxford Dictionary of World Religions, 199, accessed on February 15, 2014, http://www.encyclopedia.com/doc/1O101-Kaminomichi.html).

${ }^{32}$ Ibid., 139.

${ }^{33}$ Ibid.

${ }^{34}$ Bonciu, "The Japanese Concept of Sustainable Development at a Global Level," 3. See also Boyd and Nishimura, "Shinto Perspectives," 9-11.

${ }^{35}$ Yamamoto, "Nature in Shinto Tradition," par. 4.

${ }^{36}$ Ibid.

${ }^{37}$ Ibid.

${ }^{38}$ Callicott, Earth's Insights, 106.

${ }^{39}$ James W. Boyd and Ron G. Williams, "Reconsidering Shinto after World War II: Perspectives from the Life and thought of a Shinto Priest," accessed on September 10, 2013, www.faculty.ccp.edu/ faculty/DFreedman/HCS/boyd.pdf. 
natural world. ${ }^{40}$ Fundamental philosophical beliefs such as spiritualism, dynamism, holism, and communalism are derivable from the African panpsychic notion. ${ }^{41}$

Though traditional Africans acknowledge the presence of the vital force of the creator in all things, persons, and places; all things, persons and places are not homogenous. Aspects of nature that are awe-inspiring and mysterious, such as waterfalls and mountains, are given more reverence than others. This does not discount the general reverence that is given to all of nature. Although Africans make a distinction between the sacred and the profane, the profane does not carry some element of sacred presence, only that the sacred carries a higher presence than the profane. Religious altars, shrines, and groves are filled with a higher degree of spiritual presence than other places. The two realms, however, should be seen as complementary, not opposites; for the profane and the sacred reinforce one another, exist in company of each other in mutual accommodation. Life and all it implies exist in a communitarian and participatory paradigm. ${ }^{42}$

The African perception that the earth is sacred has actually led to environmental protection. All through Africa there are sacred groves, uncultivated forest which are left to lie fallow, the practice of totem in which many animals and plants are protected as they are seen as symbols of survival of the ethnic group. As Mike Anane has written:

That sacred groves contribute greatly towards conservation of biodiversity cannot be overemphasized. Originally, these sacred groves were based on religious and cultural beliefs, but they have since made significant contributions to the protection of wildlife and other biological resources. For example, the Boaben-Fiema monkey sanctuary, located within the moist forest deciduous zone, is richer than any other Ghanaian forest in terms of diverse types and rare species of monkeys like the Black and White Colobus and Mona monkeys. These species are considered sacred by the people of Boaban and Fiema villages. Here, the unharmed "children of the gods" have for hundreds of years come into the villages daily to eat and play. The sanctuary is also rich in trees; of about 125 known species, they include such rare ones as Pericopsis Elata. ${ }^{43}$

${ }^{40}$ Munyaradzi Felix Murove, "An African Environmental Ethic Based on the Concepts of Ukama and Ubuntu," in African Ethics: An Anthology of Comparative and Applied Ethics, ed. Munyaradzi Felix Murove (Scottsville: University of KwaZulu-Natal Press, 2009), 316.

${ }^{41}$ Yusufu Turaki, Foundations of African Traditional Religion and Worldview (Nairobi: WorldAlive Publishers Limited, 2006), 31-39.

${ }^{42}$ Francis O.C. Njoku, Essays in African Philosophy, Thought and Theology (Nekede, Owerri: Claretian Institute of Philosophy, 2002), 166.

${ }^{43}$ Mike Anane, "Implementing Agenda 21 Religion and Conservation in Ghana," accessed on January 10, 2014, http://www.un-ngls.org/orf/documents/publications.en/agenda21/12.htm. 
The questions that need be asked is that in the light of contemporary environmental challenges that have led to environmental degradation in both Japan and many regions in Africa, can the traditional wisdom from both Shinto and African Panpsychism still be useful?

In the case of Japan, some scholars are right to note that the defeat of Japan in World War II promoted a drive to modernization, westernization, and liberal democratic values, and that this move weakened traditional values and thought. ${ }^{44} \mathrm{As}$ forests have to give way to built environment, rapid industrialization and population upsurge in a small island that is just about twenty-five percent of the size of California precipitated environmental degradation and health challenges. ${ }^{45}$ T. Yamauchi avers forcefully that:

More subtly destructive was the introduction of the rich lifestyle of affluent societies, which displaced the traditional symbiotic way of life. Mass consumption and mass abandonment replaced traditional recycling systems. Indeed the industrialization of densely populated Asian countries, following the models of European and North American modernism, is a major force in the contemporary global ecological crisis. ${ }^{46}$

What is said of Japan and Asian countries is not totally different from what has happened to African countries. The impact of World War II and the colonialist ideology of imperial powers that commoditized land and its resources influenced African behaviors and patterns of living. The absorption of western ideologies of development and the drive to be at par with the West drastically affected traditional values of communalism, Ubuntu and Ukama. African communities that were once cohesive became susceptible to the coming of western multinational mining and manufacturing companies that care mainly about their profits. ${ }^{47}$

Yet all hope is not lost. Societies such as Japan, other Asian countries, and African countries have recognized the need to ameliorate, and if possible, eradicate environmental degradation. What is needed is not a total rejection of western or modern value or systems of thought, but a critical assessment of modernism and industrialization that is attentive to the rich heritage of traditional thought. ${ }^{48}$ In Japan, this will help to create a distinctive Japanese environmental philosophy, while in Africa it will create a unique African environmental ethics.

\footnotetext{
${ }^{44}$ Yamauchi, "Japan," 7.

${ }^{45} \mathrm{Ibid}$. See also Bonciu, "The Japanese Concept of Sustainable Development at a Global Level," 2; Yamamoto, "Nature in Shinto Tradition," par. 6.

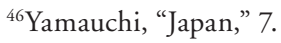

${ }^{47}$ Murove, "An African Environmental Ethic," 316.

${ }^{48}$ Callicott, Earth's Insights, 106-7.
} 


\section{CONCLUDING REFLECTIONS}

Duncan S. Ferguson propounds rightly that:

It is possible to find positive underlying truth and insight in the Shinto religion as well. The obvious one is the inherent love of nature and the deep appreciation for the beauty of nature. As in other wisdom traditions of indigenous religions, we see in Shinto the sense of being an integral part of nature and one with the vast expanse of the natural world that is in the process of evolving. Because of this profound insight, there is a sense of being a dependent part of nature and the conviction that nature must be conserved and respected. It is an understanding that points toward an ecological perspective that affirms that humans belong to the cosmos, and that relationships, interdependence, and change are essential categories that shape values and responsibilities. This paradigm, intuited in an earlier period, but now understood within a scientific framework, strongly suggests a global solidarity with all levels of life, one that is sensitive and responsive to the serious threats of global warming and other forms of environmental deterioration. ${ }^{49}$

What Ferguson writes of Shinto is applicable to African ecological wisdom. There is an awesome presence in the universe. Human life depends on the earth. There is need to thankfully and reverently respect that life force in us and in all things. It behooves humans to take care of the earth so that the earth will sustain them. The point that needs to be emphasized is that humans should recognize the mystery of life in the universe, especially the consciousness in humans. What should matter is that human persons have recognized that there is an environmental crisis precipitated by human presence and activities on the planet. What humanity should seek is what Olusegun Steven Samuel calls "any conduct that promotes the interconnectedness of all reality in a loving, peaceful, equitable, truthful, patient, tolerant (non-violent), harmonious (co-operative) way." 50

It does not matter what one calls this attitude or way of life. The important thing is that the planet and its peoples are protected and given a sustainable environment. Humanity is called to create healthy lifestyles that will help to foster a healthy and peaceful planet for the flourishing of the entire cosmic community. The recognition of the mysterious, awesome, and fascinating aspects of nature can help in the cultivation and the conservation of the earth.

${ }^{49}$ Ferguson, Exploring the Spirituality, 25.

${ }^{50}$ Olusegun Steven Samuel, "Global and General Ethics," in Applied and Practical Ethics: A Simplified Course Text, ed. Chigbo Joseph Ekwealo (Lagos: African Environmental Ethics and Values Research Group, 2012), 297. 


\section{BIBLIOGRAPHY}

Adogbo, M.P. "The Spirit World of African Peoples." In Contemporary Essays in the Study of Religions, edited by Samuel U. Erivwo and Michael P. Adogbo, vol. 1:104-23. Lagos: Fairs and Exhibitions Nigeria Limited, 2000.

Anane, Mike. "Implementing Agenda 21 Religion and Conservation in Ghana." Accessed on January 10, 2014. http://www.un-ngls.org/orf/documents/ publications.en/agenda21/12.htm.

Association of Shinto Shrines. "Nature, It is Divine, Message from Shinto." Accessed on January 10, 2014. http://www.jinjahoncho.or.jp/en/publications/nature.

Azenabor, Godwin. Modern Theories in African Philosophy. Lagos: Byolah Publishers, 2010.

Bonciu, Florin. "The Japanese Concept of Sustainable Development at a Global Level." Romanian Economic and Business Review 2 (2007): 7-13. Accessed on September 10, 2013. ftp://ftp.repec.org/opt/ReDIF/RePEc/rau/journal/SU07/ REBE-SU07-A1.pdf.

Bowker, John. "Kami no michi." In Concise Oxford Dictionary of World Religions. Accessed on February 15, 2014. http://www.encyclopedia.com/doc/1O101Kaminomichi.html.

Boyd, James W. and Tetsuya Nishimura. "Shinto Perspectives in Miyazaki's Anime Film 'Spirited Away."' Journal of Religion and Film 8, no. 2 (2004). www. unumaha.edu/jrf/Vol8No2/boydShinto.htm.

Boyd, James W. and Ron G. Williams. "Reconsidering Shinto after World War II: Perspectives from the Life and thought of a Shinto Priest." Accessed on September 10, 2013. www.faculty.ccp.edu/faculty/DFreedman/HCS/boyd.pdf.

Callicott, J. Baird. Earth's Insights: A Multicultural Survey of Ecological Ethics from the Mediterranean Basin to the Australian Outback. Berkeley: University of California Press, 1994.

Dukor, Maduabuchi. Scientific Paradigm in African Philosophy: Theistic Panpsychic Epistemology and Ontology. Saarbrucken, Germany: Lap Lamberts Academic Publishing, 2010.

Espin, Orlando O. "Pantheism." In An Introductory Dictionary of Theology and Religious Studies, edited by Orlando O. Espin and James B Nickoloff, 1000. Collegeville, Minnesota: Liturgical Press, 2007.

Ferguson, Duncan S. Exploring the Spirituality of the World Religions: The Quest for Personal, Spiritual and Social Transformation. London: Continuum, 2010.

Gehman, Richard J. African Traditional Religion in Biblical Perspective. Nairobi: East African Educational Publishers, 2005. 
Gleason, Wendy. "Searching for Shinto: The Interplay of Politics and Religion from Yamato to the Heian Era," 2007. Accessed on September 10, 2013. www.pcc. edu/library/sites/default/files/searching-for-shinto.pdf.

Hara, Masakazu. "Shinto." Encyclopedia of Science and Religion. 2003. Encyclopedia.com. Accessed October 15, 2013. http://www.encyclopedia.com/ doc/1G23404200466.html.

Ives, Christopher. "Japanese Love of Nature." In Encyclopaedia of Religion and Nature, edited by Bron Taylor, 899-900. London: Continuum, 2005.

Kisala, Robert J. "Japanese Religions." In Religions in the Modern World: Traditions and Transformations, edited by Linda Woodhead, Hiroko Kawanami and Christopher Partridge, 147-71. London: Routledge, 2009.

Markham, Ian S. and Christy Lohr, ed. A World Religions Reader. Malden, MA: Wiley-Blackwell, 2009.

Mbaegbu, Celestine C.A. Hermeneutics of God in Igbo Ontology. Awka: Fab Educational Books, 2012.

Mbiti, John S. Introduction to African Religion. Nairobi: East African Educational Publishers, 1991.

Murove, Munyaradzi Felix. "An African Environmental Ethic Based on the Concepts of Ukama and Ubuntu." In African Ethics: An Anthology of Comparative and Applied Ethics, edited by Munyaradzi Felix Murove, 315-31. Scottsville: University of KwaZulu-Natal Press, 2009.

Nobutaka, Inoue. "Perspectives towards Understanding the Concept of Kami," Institute for Japanese Culture and Classics, Kokugakuin University, 1998. Accessed on September 10, 2013. www2.kokugakuin.ac.jp/ijcc/wp/cpjr/kami/ into.html.

Njoku, Francis O.C. Essays in African Philosophy, Thought and Theology. Nekede, Owerri: Claretian Institute of Philosophy, 2002.

Olupona, Jacob. "Religion and Ecology in African Culture and Society." In The Oxford Handbook of Religion and Ecology, edited by Roger Gottlieb, 259-82. Oxford: Oxford University Press, 2006.

Samuel, Olusegun Steven. "Global and General Ethics." In Applied and Practical Ethics: A Simplified Course Text, edited by Chigbo Joseph Ekwealo, 270-97. Lagos: African Environmental Ethics and Values Research Group, 2012.

Tempels, Placid. Bantu Philosophy. Paris: Presence Africaine, 1959.

Turaki, Yusufu. Foundations of African Traditional Religion and Worldview. Nairobi: World Alive Publishers Limited, 2006.

United Nations. Declaration of the Rights of Indigenous Peoples, Article 31. Accessed on May 10, 2013. http://www.un.org/esa/socdev/unpfii/documents/ DRIPS_en.pdf. 
Yamamoto, Yukitaka. "Nature in Shinto Tradition." Accessed on September 20, 2013. www.Csuchico.edu/-gwilliams/tsa/peace5.html.

Yamauchi, T. "Japan." In Encyclopaedia of Environmental Ethics and Philosophy, edited by J. Baird Callicott and Robert Frodeman, vol. 2:6-8. Detroit: Gale Cengage Learning, 2009.

Mark Omorovie Ikeke, a priest of the Catholic Diocese of Warri, Nigeria, holds an $\mathrm{MA}$ and a $\mathrm{PhD}$ in Religious Education from Fordham University, New York; and an MA in Philosophy and a PhD in Environmental Philosophy from Nnamdi Azikiwe University, Awka Nigeria. He is a lecturer in the Department of Religious Studies and Philosophy, Delta State University, Abraka, Nigeria. His main research interest is in environmental ethics. He may be sent an email at ikeke7@yahoo.com. 